\title{
Effect of Dayak Onion (Eleutherine palmifolia (L) Merr. Crude Extract on Histopatology of Gills, Kidney, Liver and Muscle of Aeromonas hydrophila- Infected Carp (Cyprinus carpio)
}

\author{
Maftuch ${ }^{1}$, H. Suprastyani ${ }^{1}$, E. Sanoesi ${ }^{1}$, N. Farida ${ }^{1}$, I. Fransira ${ }^{1}$, N. Habibah ${ }^{1}$, Dwi R. \\ Fatmawati $^{1}$, R. Rinaldi ${ }^{1}$, Ika K. Nisyak ${ }^{1}$, D. Ardiansyah ${ }^{1}$, Asep A. Prihanto ${ }^{2}$ \\ ${ }^{1}$ Department of Aquaculture, Faculty of Fisheries and Marine Sciences, Brawijaya University, Malang \\ ${ }^{2}$ Department of Fishery Product Technology, Faculty of Fisheries and Marine Sciences, Brawijaya University, Malang
}

\begin{abstract}
Carp (Cyprinus carpio) is one of important freshwater cultivated fish species in Indonesia. Aeromonas hydrophila is accounted as potential pathogenic bacteria in Carp. In this study we investigated the effectiveness of crude extract of Dayak onion (Eleutherine palmifolia (L.) Merr) for the treatment of A. hydrophila infected fish. Furthermore, alteration of histophatology of several organs, gills, kidney, liver and muscle were investigated. Crude Extract of Dayak Onion (Eleutherine palmifolia (L) Merr. (CEDO) with the doses of 50,60, 70 and 80 ppm were used for treatment of $A$. hydrophila infected carp for 11 days. Prior to investigation of histopatology of gills, kidneys, hearts, muscle, the Carp was moved to fresh-non infected fish tank. The Result indicated that gill experienced Hyperplasia, Fusion, Necrosis. Kidney experienced Degeneration, Congestion, Necrosis. Liver experienced the vacuole degeneration, congestion, Melano macrophages, necrosis. Muscle experienced Edema and necrosis. But fish treated with $80 \mathrm{ppm}$ treatment showed less damage and tissue repair.
\end{abstract}

Keywords: E. palmfolia (L.) Merr, A. hydrophila, C. carpio, Histopathology, Gills, Kidney, Liver, Muscle

\section{INTRODUCTION}

Carp (Cyprinus carpio) is a fresh water fish species. It is fast growth species. Hence, it is an important species for Indonesia for aquaculture development programs. This species can be used for fulfilling protein needs for human. Year by year, more people consume carp [1]. Unfortunately, fish disease which is caused by Aeromonas sp. Motile Aeromonas Septicemia (MAS) caused by the bacterium Aeromonas hydrophila is one of aquaculture problem [2].

Prevention and treatment efforts are commonly applied to infected fish. One of the effort is using chemical drugs such as malachite green, formaline and hydrogen peroxide [3]. However, the use of chemicals tend to be environmentally dangerous due to its toxic compounds. Along with the trend to food safety and the environment issues, it is expected that the fish disease prevention methods should be safe for human and environment

Alternative treatment to inhibit the bacterial disease in fish is by using natural compound such as herbs and phytochemical compounds. Dayak onion (Eleutherine palmifolia (L.) Merr) have many antimicrobial compounds. According to Hidayah et al.[4], Dayak onion, a typical plant of Central Kalimantan has an potency to be applied as antimicrobial source. The dayak onion contains secondary metabolites naftokuinon group which is known as antimicrobial. Furthermore, flavonoid, glycosides, steroids, tannins and other phenolic, exist in Dayak onion.

In our preliminary analysis we confirm that Dayak Onion has antibacterial activity against $A$. hydrophila. Hence, in this study we investigate the effect of Dayak onion extract on the histology alteration of gills, kidney, liver and muscle of carp (C. carpio) after it was infected by $A$. hydrophila.

\section{MATERIALS AND METHODS}

\section{Preparation of Animal Test}

The fish ( $C$. carpio) were obtained from local breeding company of Punten, Batu City. The fish with approximately 7-12 cm of total length were used for further experiment. The fish are fed

Correspondence address:

Maftuch

Email : maftuch@ub.ac.id

Address : Department of Aquaculture, Faculty of Fisheries and Marine Sciences, Brawijaya University 
pellets two times a day in the morning and afternoon.

\section{Dayak Onion Extraction}

Dayak Onion (E. palmifolia (L) Merr.) was obtained from Oro-oro dowo traditional market, Malang City. Sample was dried and then it was grinded by using a blender. Extraction procedure followed Prihanto et al. [5] with slight modification. The grinded Dayak Onion was weighed and then mixed with ethanol solvent $96 \%$ in a $1000 \mathrm{ml}$ beaker glass with ratio of 1:4. Then it was macerated for 24 hours. After maceration, It was filtered and evaporated by using rotary evaporator. Thus, it produced crude extract in a paste form.

\section{Bioassay}

Eighteen aquariums with size of $40 \times 40 \times 40$ $\mathrm{cm}^{3}$ were used for cultivation tanks. Each tank was supplied with oxygen aeration. Each aquarium was filled with 15 fish that had previously been in acclimation for 3 days. Prior to Dayak Onion extract treatments, the fish were infected by $A$. hydrophila $\left(\times 10^{8}\right)$ for 24 hours. The fish were then transferred to the aquarium containing Dayak onion extract with several extracts dosage. The dose were 50, 60, 70 and 80 ppm. The treatment occurred for 11 hours. The fish were taken from each aquarium and continuing to the free extractaquarium for the rest of 3-7 days.

\section{Histology analysis}

Observations were based on clinical symptoms of the fish and the number of fish that died during the maintenance period. The organs were put for histopathological analysis. Organs were put into appendorf and given a preservative such as formalin 10\%, for further histopathology analysis. Analysis of histopathology was followed Oluwatoyin[6].

Histopathological stage is making preparations fixation stage, the stage of dehydration, clearing stage, the stage of impregnation, embedding stage, the stage of premises using HE staining tissue (Haematoxylin eosin) and the mounting stage. The mounted sections were viewed under the microscope using different objectives and the result was taken.

\section{RESULTS AND DISCUSSION Gills Histopathology}

Common carp gills normal conditions (Figure $1 \mathrm{~A}$ and $1 \mathrm{~B})$, showed normal histology forms, with the appearance of secondary lamella looks clear and orderly. The gills infected with bacteria (Figure 1 C, D, E and F) experienced harsh alterations such as hyperplasia, fusion and necrosis. Hyperplasia will cause by excessive edema and inhibition of mucus production. Gill is the main target of infection. Hence, Gill is the main organ which experienced severe damages.

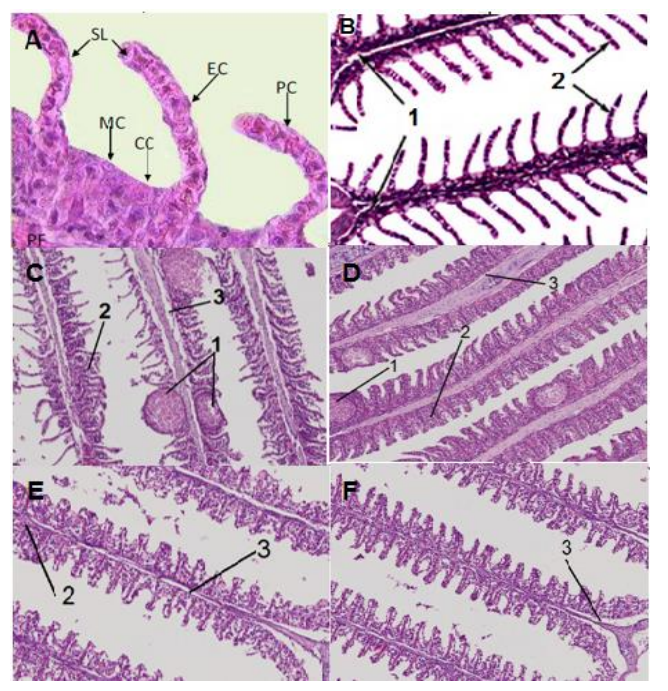

Figure 1. Histology of the gill. (A) normal gill tissue according to Hadi and Alwan, (2012): (SL) secondary lamella, (MC) mokus cells, (CC) chloride cells, (PC) cells pillar, (EC) epithelial cells). (B) normal gill tissue: (1) the primary Lamell, (2) secondary lamella. (C) dose of 50 ppm. (D) dose of $60 \mathrm{ppm}$. (E) dose of $70 \mathrm{ppm}$. (F) dose of 80 ppm. (1) Hyperplasia, (2) Fusion, (3) Necrosis. Magnification of 400x. (Research Documentation).

The gills recovery process of common carp gill was significantly affected by CEDO. Treatment of different doses of CEDO significantly affected occurred hyperplasia. The more the dose the alteration of gill was decrease. Dayak onion contains flavonoids, saponins and tannins. In accordance with the statement In several reports, phytochemical compound has an ability to recover the damages cell [7].

Furthermore, according Kim et al.[8], secondary bioactive compounds are most influential in the process of wound healing include saponins which act as antibacterial, hemostatic tannins as well as astrigensia and flavonoids act as antioxidants and anti-inflammatory. Tannin compounds act as an antiseptic on the wound surface, working as bacteriostatic normally used for infections of the skin, mucosa and fight infection in the wound. 


\section{Kidney Histopathology}

Normal kidney conditions was shown in Figure $2 \mathrm{~A}$ and $2 \mathrm{~B}$. In contrast, 2C, 2D, 2E, $2 \mathrm{~F}$ showed several cell damages. Degenerated and congested cells and necrosis were occurred in the kidney cells. Naeemi et al.[9], reported that damage to the kidney could be found that some changes such as a reduction in hematopoietic tissues, depreciation tubular degeneration that occurs in the epithelial cells of renal tubular necrosis were found in the kidneys.

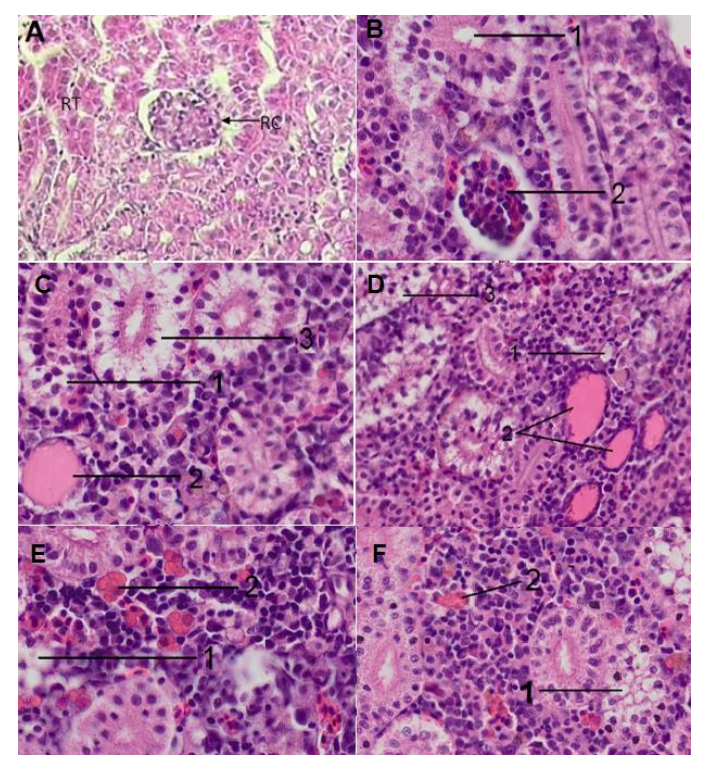

Figure 2. (A). Pictures of normal kidney tissue and according to Hadi and Alwan, (2012): (RT) renal tubules, (RC) On normal renal glomerulus visible and Bowman's space. (B) Pictures of normal kidney tissue: (1) distal tubules, (2) Hematopoietic tissue. (C) dose of $50 \mathrm{ppm}$. (D) dose of $60 \mathrm{ppm}$. (E) dose of $70 \mathrm{ppm}$. (F) dose of 80 ppm. (1) Degeneration, (2) Congestion, (3) Necrosis. Magnification 200x. (Research Documentation).

The use of CEDO with soaking method at different doses significantly affected degeneration, congestion and necrosis damage. This is because the active ingredient contained in the crude extract of dayak onion. Wahjuningrum et al.[10], flavonoids are natural changes in responses, such as from the results of several studies showing the ability of flavonoids in changing the body's reaction to allergens, viruses, and cancer-causing. These substances also have anti-allergy activity, anti-inflammatory, antimicrobial and anticancer. Smaller the dose, indicated more cell alterations. It can be conclude that the higher the dose the better of the treatment.

\section{Liver Histopathology}

The infection of $A$. hydrophila on fish heart tissue started to fall apart and found flaws such as vacuoles degeneration (Figure 3B.). The cell experienced swelling of cells in which hepatocytes swell and congestion. Melano macrophage which is generation of melanin pigment in liver cells due to liver cell damage. Necrosis also occurred which is indicated by cell death or bleeding due to bacterial infection.

Vacuole degeneration is a condition in which the liver cells appear enlarged (Figure 3C, 3D, 3E, $3 F)$. This swelling of the liver due to an increase in permeability of the cell, where the cells failed to maintain ion homeostasis and fluid. According to Hadi and Alwan[11], swelling of the liver cells characterized by the presence of vacuoles caused swollen hepatocytes. This swelling indicates an imbalance between the synthesis of substances in the parenchymal cells and the circulation system.

In this result, CEDO was significantly affected vacuole degeneration. According to Fasinu et al. [12], Medicinal plants extract which contain flavonoids are known to have antimicrobial activity. Chusnie and Lamb.[13], adding the antimicrobial activity of flavonoids can be explained by the inhibition of bacterial metabolism and the absorption of substances necessary for bacterial growth. Congestion is blood increase in tissue which is caused by impaired blood circulation (Figure 3G, 3H, 3I, 3J). The disruption caused by the increased volume of blood in the capillaries [9].

Congestion and Melano macrophages damage is an indicator that the fish experienced stress. David and Kartheek [14], adding that the indicators of stress on the fish one of which Melano macrophages. Phytochemical compound will protect the worse alteration due to bacterial infection. Alabi et al.[15], tannin work agglomerate bacterial cytoplasm of cells so that the metabolism of the bacteria will be disturbed. Noga[16], melanomakrofag is tissue damage observed in the liver of fish. In healthy fish usually are melano macrophage solid round shape that has a varied amount of pigment. This is because the number will increase when the fish is stressed. This increase resulted from the activity of melanin pigment in it. the antimicrobial mechanism of flavonoid there are three kinds, namely first by inhibiting the synthesis of nucleic acids. 


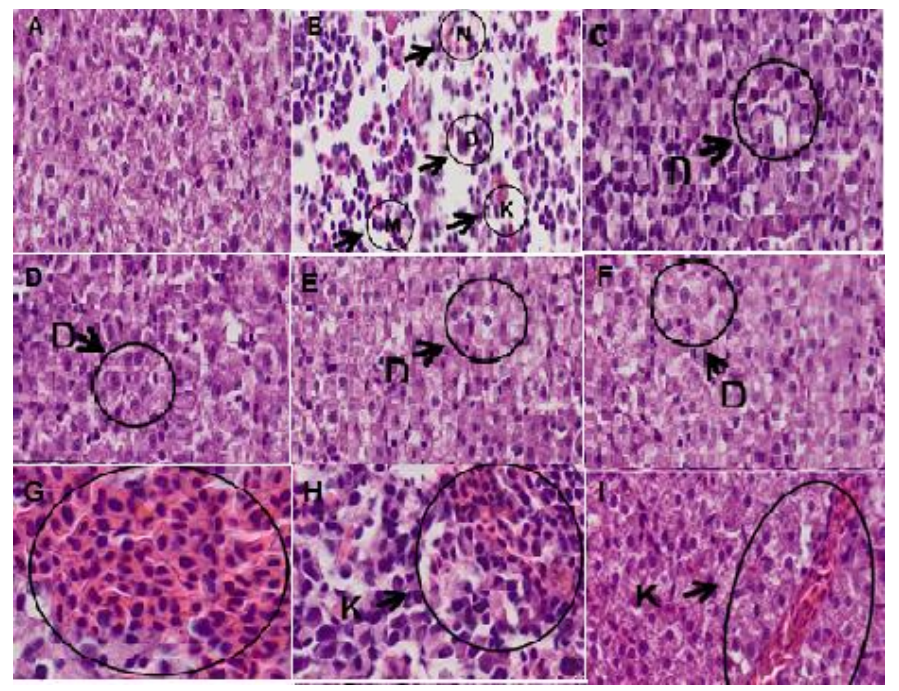

Figure 3. (A) Normal liver tissue without treatment. (B) Liver tissue infected with bacteria A. Hydrophila. (C) dose of $50 \mathrm{ppm}$. (D) dose of $60 \mathrm{ppm}$. (E) dose of $70 \mathrm{ppm}$. (F) dose of $80 \mathrm{ppm}$. Liver tissue experienced: The vacuole degeneration (D). Congestion (K). Melano macrophages (M). Necrosis (N). Experiencing Congestion (in G, H, I). Magnification 400x. (Research Documentation).

The second way is by inhibiting the function of the cytoplasmic membrane. The third way to inhibit the metabolism of energy[17].

Tannin is an antimicrobial compound that has the ability to damage the bacterial cell wall and inhibit bacterial growth. Tannins can bind to lipoteikoit acid on the surface of bacterial cells. Tannins can inhibit bacteria by destroying the bacterial plasma membrane. Damage to the cell membrane can prevent foodstuffs or bacteria enter the necessary nutrients to produce energy[18].

\section{Muscles Histopathology}

The result of muscle histopathology analysis was depicted in Figure 4. Normal fish muscle shows that the striated muscle with one another have dense tissue, as well as the smooth muscle structure is still clearly visible (Figure 4A). This indicates that the structure of the muscles in the common carp (C. carpio) is normal. Fish muscle with infection without treatment showed tissue damages, necrosis and edema (Figure 4B). In treated fish, the muscle also experienced damages (Figure 4C, 4D, 4E, 4F).

In this study, the use of CEDO affected the necrotic damage. According to Amanda[19], while the content of bioactive compounds found in dayak onion bulbs consisting of alkaloids, flavonoids, and tannins. This result was also corroborated by the study of Subramaniam, et al. [20]. In his study, Eleutherine palmifolia contains Phenols, Sterols, Phlobatannins and steroids where in many research indicated that those compound have antibacterial activity[21].

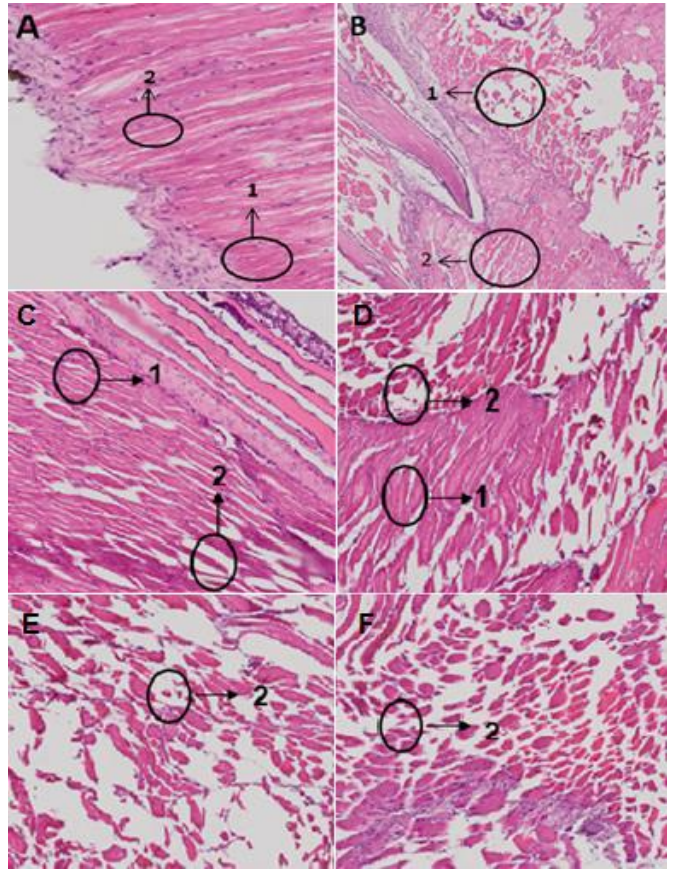

Figure 4. Muscles Histopathology of carp (A) Negative Control: (1) smooth muscle, (2) the structure of striated muscle tissue histopathology. (B) Positive Control: (1) necrosis (2) Edema. (C) dose of 50 ppm. (D) dose of $60 \mathrm{ppm}$. (E) Dose $70 \mathrm{ppm}$. (F) dose of $80 \mathrm{ppm}$. (1) Edema and (2) necrosis. Magnification 400X. (Research Documentation).

\section{CONCLUSION}

Based on the results of research that has been done, it was concluded that the use of crude extract of dayak onion (Eleutherine palmifolia (L.) Merr) effected histology of Aeromonas hydrophila infected common carp organs, gills, kidney, liver 
and muscle. In this result, it also concluded that the recovery of the organs was dose dependent.

\section{ACKNOWLEDGEMENTS}

We would like to thank Dr. Widodo, for his technical assistance and publications.

\section{REFERENCES}

[1]. Skibniewska K.A., Zakrzewski J., Kłobukowski J., Białowis H., Mickowska B., Guziur J., Walczak Z., Szarek J. 2013. Nutritional value of the protein of consumer carp Cyprinus carpio L. Czech Journal of Food Sciences, 31: 313-317

[2]. Karunasagar I., Karunasagar, I., Otta, S.K., 2008. Disease Problems Affecting Fish in Tropical Environments. Journal of Applied Aquaculture, 13: 231-249

[3]. Meyer, F. P. 1991. Aquaculture disease and health management. J Anim Sci. 69 (10): 42018.

[4]. Hidayah, A.S., Mulkiya, K., Purwanti, L. 2015. Antioxidant assay of Dayak Onion seed (Eleutherine bulbosa Merr). Proceeding of SPeSIA Unisba Research. 397-404. (In Indonesian).

[5]. Prihanto, A.A, Firdaus, M., Nurdiani R., 2012. Anti-Methicillin Resistant Staphylococcus aureus (MRSA) of Methanol Extract of Mangrove Plants Leaf: Preliminary Report. Drug Invention Today. 4 (8): 439-440

[6]. Oluwatoyin, A.S. 2011. Histopathology of Nile Tilapia (Oreochromis niloticus) juveniles exposed to aqueous and ethanolic extracts of Ipomoea aquatica leaf. International Journal of Fisheries and Aquaculture. 3(14): 244-257

[7]. Akinsanyaa, B., Utoha, O.U., Ukwa U.D. 2016. Toxicological, phytochemical and anthelminthic properties of rich plant extracts on Clarias gariepinus. The Journal of Basic \& Applied Zoology 74: 75-86

[8]. Kim, S.Y. Cho, IK., Jeong, M.J. 2011. Therapeutic Effect of Total Ginseng Saponin on Skin Wound Healing. J Ginseng Res. 35(3): 360-367

[9]. Naeemi, A.S., Jamili., S., Shabanipour, N. 2013. Histopathological change induced in the liver of the Caspian kutum fry after acute exposure to the anionic surfactant. European Journal of Zoological Research. 2: 100-105

[10]. Wahjuningrum, D., N. Ashry dan S. Nuryati. 2008. Utilization Ketapang (T. cattapa) leaf extract for treatment of Aeromonas hydrophila infected cat fish (Pangasionodon Hypophthalmus). Jurnal Akuakultur Indonesia, 7 (1) : 79-94 (In Indonesian)

[11]. Hadi, A.A, and Alwan, S.F. 2012. Histopathological changes in gills, liver and kidney of fresh water fish, Tilapia zilli, exposed to aluminum. Int J Pharma Life Sci. 3:20712081

[12]. Fasinu, P.S., P Bouic, P.J., and Rosenkranz, B. 2012. An Overview of the Evidence and Mechanisms of Herb-Drug Interactions. Front Pharmacol. 3: 69.

[13]. Chusnie, T.P.T., Lamb, A.J. 2011. Recent Advances in Understanding The Antimicrobial Proprties of Flavonoids. Int. J. Antimicrob. Agents. 38 (2), 99-107.

[14]. David M. and Kartheek R.M. 2015. Histopathological alterations in spleen of freshwater fish Cyprinus carpio exposed to sublethal concentration of sodium cyanide Open Veterinary Journal. 5(1): 1-5

[15]. Alabi, OA., Haruna, MT., Anokwuru, CP., Jegede, T., Abia, H., Okegbe, V. and Esan, E. 2012. Comparative studies on antimicrobial properties of extracts of fresh and dried leaves of Carica papaya (L) on clinical bacterial and fungal isolates. Pelagia Research Library. 3 (5):3107-3114

[16]. Noga E.J. 2010. Fish Disease; Diagnosis and Treatment. Second Edition. Wiley Blackwell. Hoboken. NJ

[17]. Cushnie, T.P.T, Lamb, A.J. 2005. Antimicrobial Activity of Flavonoids. Int. J. Antimicrob. Agents. 26 (5), 343-356.

[18]. Doss A, Mubarack HM and Dhanabalan R 2009. Antibacterial activity of tannins from the leaves of Solanum trilobatum Linn. Indian J Sci Technol. 2(2): 41-43

[19]. Amanda F.R. 2014. effectiveness of Dayak Onion (Eleutherine palmifolia L. Merr.) on the inhibition of Escherichia coli. Minor thesis. Syarif Hidayatullah Islamic University. Jakarta. (In Indonesian)

[20]. Subramaniam, K., Suriyamoorthy, S., Wahab, F., Sharon, F.B., Rex, G.R., 2012. Antagonistic activity of Eleutherine palmifolia Linn. Asian Pacific Journal of Tropical Disease (2012)S491S493

[21]. Padhi, L and Panda S.K., 2015. Antibacterial activity of Eleutherine bulbosa against multidrug-resistant bacteria. Journal of Acute Medicine 5: 53-61 